Margita Jágerová

ORCID: https://orcid.org/0000-0001-9793-2880

Katedra etnológie a folkloristiky, Filozofická fakulta

Univerzita Konštantína Filozofa v Nitre, Slovensko

\title{
„Prosím nepálit' sviečky, ešte žijeme“ - k problematike „zabývania sa“ v priestore cintorína
}

\author{
"Don't light the candle, please, we are still alive" - preparing \\ one's own "residence" at a cemetery
}

\begin{abstract}
An analogous perception of the grave as a "residence" for the deceased belongs to the archaic sphere within the traditional spiritual culture of many communities, not only within Europe. Even today, such an attitude can be observed in the behavior, imagination and reflection of our contemporaries, especially those belonging to the oldest generation. In the context of these ideas, such persons tend to prepare their own burial place even though they are still alive. The paper is focused on the current forms of preparing one's own "residence" at a cemetery, and the attitudes attendant on this phenomenon. Presented material is based on the long-term ethnological research of the problems in the rural environment of Slovakia. It presents its genesis, analyzes the strategies of preparing burial site (alternatively: a place for the insertion of a urn), defining the motives of such behavior, and the individual forms of "occupying" the place at the cemetery even though the person in question is still alive.
\end{abstract}

Key words: cemetery, an "after-death dwelling”, preparation of a grave, tomb, funeral rites

Analogická predstava o hrobe ako o „dome“ pre zosnulého patrí k archaickým v rámci tradičnej duchovnej kultúry mnohých spoločenstiev, a to nielen v rámci Európy. Aj v súčasnosti možno sledovat takýto prístup v správaní, predstavách a uvažovaní súčasníkov, najmä z radov najstaršej generácie. V kontexte týchto predstáv pristupujú k príprave vlastného miesta posledného odpočinku ešte počas svojho života. Hoci má tento jav svoj pôvod v mestskom prostredí, resp. v prípade vyššie postavených, majetných rodín, v priebehu niekolkých desatročí sa rozšíril aj v rôznych vrstvách obyvatel’ov vidieka. Príspevok sleduje aktuálne spôsoby „zabývania sa" v priestore cintorína, prístup k tomuto javu na základe dlhodobého sledovania problematiky vo vidieckom prostredí Slovenska. Približuje jeho genézu, analyzuje stratégie prípravy miesta na pochovanie 
(prípadne na vloženie urny), pričom definuje motívy takéhoto správania, jednotlivé podoby „obsadzovania“ miesta $\mathrm{v}$ cintoríne ešte počas života dotyčného.

Kl'účové slová: cintorín, „bývanie po smrti“, príprava hrobu, hrobka, pohrebné obyčaje

Odebrano / Received: 31.01.2019

Zaakceptowano / Accepted: 27.08.2019

Z hladiska obyčajových úkonov možno cintorín pokladat za miesto, kde dochádza k finálnej separácii mŕtveho zo spoločenstva živých - teda k dokončeniu jednej z fáz pohrebných obyčají. Pozostalí si budujú vzt̉ah ku konkrétnemu miestu v rámci cintorína predovšetkým prostredníctvom smrti a následného pochovania blízkeho človeka. Hrob predstavuje „sakrálny locus“ označujúci pozemskú lokalizáciu „druhého“ sveta, ktorý sa stáva legitímnym miestom stretnutia živých s mŕtvymi ${ }^{1}$. Cintorín je priestor slúžiaci na pochovanie a hoci je primárne určený mŕtvym, na druhej strane ho výrazne dotvárajú živí, ktorí budujú a následne sa starajú o hroby svojich zosnulých. Za posledné desatročia sa však objavil nový fenomén - príprava vlastného hrobu, „svojho“ miesta na cintoríne ešte počas života dotyčného. Ide o „obsadzovanie“ tohto priestoru ešte žijúcimi ako plánovaný, ciel'avedomý proces, využívajúc pritom rôznorodé stratégie.

Názov príspevku bol inšpirovaný fotografiou zachytávajúcou dvojhrob manželskej dvojice, na ktorom bol umiestnený nápis: „Prosim nepálit’ sviečky ešte žijeme“. Išlo evidentne o prázdny hrob, vybudovaný a pripravený na pochovanie jeho majitel'ov/nájomníkov. Ako uvádza prostredníctvom jedného zo svojich informátorov Sikora ${ }^{2}$ - „v živote človeka prichádza taký moment, ked' sa začína zaujímat’ o svoj hrob, ako sa predtým zaujímal o bývanie“. Analogická predstava o hrobe ako o „dome“ pre zosnulého patrí k archaickým $\mathrm{v}$ rámci tradičnej duchovnej kultúry mnohých spoločenstiev, a to nielen $\mathrm{v}$ rámci Európy. Takéto vnímanie sa objavovalo vo folklórnom materiáli spojenom s pohrebnými obyčajmi - v pohrebných plačoch a piesňach ${ }^{3}, \mathrm{kde}$ už samotná truhla alebo hrob či cintorín boli stotožňované s „novým domom“ alebo „novým bývaním“ pre mŕtveho. Podnes sa táto analógia objavuje $\mathrm{v}$ predstavách a výpovediach príslušníkov najstaršej generácie. $V$ kontexte týchto predstáv pristupujú k príprave vlastného hrobu (resp. urnového miesta).

Príspevok sleduje aktuálne spôsoby „obsadzovania“ a „zabývania sa“ v priestore cintorína, budovanie hrobu ešte počas života. Tento proces zahŕňa rezerváciu a vymedzenie

1 Plotnikova 1999, s. 210.

2 Sikora 1986, s. 57.

3 Zo slovenských autorov sa problematike pohrebných plačov venovala Burlasová 2009, ktorá taktiež poukazuje na tematiku „domu“, do ktorého mŕtvy odchádza. Podobne pozri práce z rôznych oblastí Európy, napr. Plotnikova 1999, Sedakova 1990, Vakarelski 1990, Kligman 1988 a i. 
hrobu, prípravu náhrobníka s obrubou, prípadne aj s platňami (krytmi) na povrchu ${ }^{4}$, niekedy aj s vybudovaním vnútorných priestorov či dokonca chodníkov okolo hrobu, neraz aj lavičky. Východiskovým materiálom boli informácie z etnologického terénneho výskumu ${ }^{5}$, pričom túto problematiku sledujem v rôznych vidieckych lokalitách Slovenska už dve desatročia. Ciel’om príspevku je poukázat na genézu tohto javu, rôzne stratégie a podoby prípravy „bývania“ po smrti, dôvody a motivácie takéhoto konania, taktiež jeho vplyv na obyčajové úkony v rámci pohrebného obyčajového cyklu.

\section{Genéza sledovaného javu}

$\mathrm{V}$ úvode je nutné zdôraznit, že tento jav sa objavil v mestskom prostredí, resp. u privilegovaných vrstiev, ktoré si ešte počas života budovali rodinné hrobky. V tradičnom vidieckom prostredí dlhodobo fungovala prax pochovávat každého zosnulého do osobitného hrobu, a to podla poradia, v akom umierali (pochovávalo sa „do radu“).

$\mathrm{Na}$ základe získaných informácií sa príprava vlastného hrobu ešte počas života začala na Slovensku vo vidieckom prostredí objavovat’ v druhej polovici 20. storočia, čo súviselo s rozvojom kamenárskeho sektora a s cenovou dostupnostou trvácnejších materiálov pre širšie vrstvy obyvatel'ov. Najmä náhrobníky z „umelého“ kameňa (zmes cementu a drveného kameňa), zriedkavejšie $\mathrm{z}$ nákladnejšieho prírodného kameňa, zaručovali trvalejšie označenie hrobu. Tento jav sa začal v rurálnom prostredí uplatňovat v prípade úmrtia jedného $\mathrm{z}$ manželov. Ich pochovávanie do jedného hrobu sa tu začalo praktizovat’ najmä od šest'desiatych, frekventovanejšie od sedemdesiatych rokov 20. storočia ${ }^{6}$, pričom ojedinelé prípady dokladajú aj staršie materiály z prvej polovice 20 . storočia $^{7}$. Súviselo to jednak so zmenou staršieho ponímania hrobu ako individuálnej jednotky, reprezentujúcej jednu osobu, na druhej strane s vyzdvihovaním faktu manželského spolužitia. Manželský partner, ktorý ostal nažive, si zabezpečil miesto pochovania

${ }^{4}$ Kamenné platne (kryty) na hrobe sa začali frekventovane objavovat zhruba v posledných dvoch-troch desatročiach, ked' sa pri novo vybudovaných hroboch stali takmer výlučnou formou úpravy ich povrchu.

5 Výskum zameraný na túto tému prebieha už od konca 90. rokov v rôznych vidieckych oblastiach Slovenska, pričom do príspevku som zakomponovala výsledky výskumov z nasledovných lokalít - Soblahov (okres Trenčín), Vlachovo (okres Rožňava), Liptovská Teplička (okres Poprad), Malé Dvorníky (okres Dunajská Streda), Nové Sady, Malé Zálužie, Lužianky (okres Nitra), Likavka, Valaská Dubová, Liptovské Sliače, Liptovská Osada (okres Ružomberok), Dačov Lom, Sucháň (okres Velký Krtî́), Šumiac, Telgárt, Polomka (okres Brezno), Záskalie (okres Považská Bystrica), Súlov (okres Bytča).

${ }^{6}$ V mestskom, ale už aj vo vidieckom prostredí sa za posledné obdobie objavujú iné tendencie - v mnohých prípadoch sa truhly manželov pochovávajú na seba, nie vedl’a seba, čo súvisí s nedostatkom miesta a zvýšenými nákladmi na získanie hrobu. Jedno-hrob stojí ovela menej ako dvojhrob, najmä čo sa týka použitého materiálu (ohrada, kryty), čiastočne aj pomníka. Zhotovenie jedno-brobu tak môže byt v honosnejšom prevedení, z lepšieho materiálu, nakol'ko dvojhrob z umelého (lacnejšieho) kameňa by stál takmer ako jedno-hrob z drahšieho prírodného kameňa.

7 Ojedinelé doklady o spoločnom hrobe manželov možno vidiet’ na fotografiách náhrobníkov v staršej literatúre zo 40. rokov 20. storočia od Bednárika (1949), ale aj Aláča (2015) v prípade starých kamenných dvoj-náhrobníkov z Novohradu. 
v spoločnom dvojhrobe, aj s uvedením svojho mena a dátumu narodenia na náhrobníku. Z hl'adiska technických možností bolo výhodnejšie umiestnit všetky údaje na náhrobník už pri jeho zhotovovaní, nakol'ko ich dodatočné dorábanie spôsobovalo viaceré komplikácie, resp. nerovnakú kvalitu nápisov ${ }^{8}$. Ku koncu 70. a v 80. rokoch 20. storočia sa začali ojedinele objavovat prázdne, vopred pripravované hroby manželských dvojíc, zriedkavejšie jednotlivcov. Vo viacerých skúmaných lokalitách prvými takýmito prípadmi bud' bezdetní manželia, ktorí sa chceli takouto formou „zabezpečit“ na starobu, alebo lepšie situovaní jednotlivci snažiaci sa investovat’ našetrené peniaze ${ }^{9}$. Tento stav súvisel nielen s premenami vo vnímaní priestoru cintorína, ale aj so zvyšovaním životnej úrovne obyvatelov počas socializmu. Vtedajšiu situáciu s určitou nadsádzkou zobrazuje aj scéna zo známeho československého filmu Vesničko má středisková $(1985)^{10}$, v ktorom jedna z hlavných postáv konštatovala: „Lidé nevědí, co s penězma. Von má barák ${ }^{11}$, televizor, auták a tak si ř́ká - co ještě nemám? Hrobku.“

Po zmene spoločensko-politickej situácie po roku 1989 sa objavili d’alšie okolnosti, ktoré prispeli k posilneniu snahy mat vopred pripravený hrob. Transformácia spoločnosti a hospodársko-ekonomické reformy spôsobili neistotu hodnoty peňazí. V tomto období nastal prílev nových materiálov a technológií v rôznych oblastiach, kamenársky sektor nevynímajúc. Začali sa dovážat' mnohé druhy prírodných kameňov rôznych tvarov, kompletné hrobové zostavy z prírodného kameňa ${ }^{12}$ sa stávali dostupnejšími pre čoraz širší okruh záujemcov. Nastúpila povinnost̉ platił nájom za hrobové miesta, samosprávy začali kontrolovat užívatel'ov hrobov prostredníctvom vyberania poplatkov za jednotlivé miesta. $V$ mnohých lokalitách pristúpili aj k opätovnému využívaniu starších hrobov, ktoré si mohli prípadní záujemcovia vopred rezervovat. V dôsledku

\footnotetext{
${ }^{8} \mathrm{~V}$ prípade náhrobníkov z umelého kameňa (v kamenárskej terminológii nazývaného terazo) sa akékolvek informácie a zobrazenia kedysi umiestňovali bud' na sklenené opaxitové čierne tabule (technikou pieskovania alebo kombinácie pieskovania a leptania kyselinou; leptali sa však len obrázky, nie texty), alebo na kamennej čiernej tabul'ke zaliatej v umelom kameni, na ktoré sa údaje vysekávali ručne. Boli pozlátené plátkovým zlatom (najdrahší variant), bronzovým práškom alebo „postriebrené“ hliníkovým práškom. V prípade detských hrobov sa používalo biele opaxitové sklo.

${ }^{9}$ Pozri viaceré konkrétne údaje uvádzané v publikácii Jágerová 2008, s. 174 - 176. Ak sa v jednotlivých lokalitách hrobky objavili už v čase socializmu, išlo predovšetkým o majetné rodiny, členovia ktorých v minulosti pracovali v zahraničí ("ti, čo prišli z Ameriky“), prípadne prípravu hrobu ešte počas života ako prví zrealizovali „bohatší gazdovia“.

${ }^{10}$ Ide o film J. Menzla z roku 1985 - Vesničko má středisková (My sweet little village), okrem iného nominovaný aj na cenu americkej Akadémie filmového umenia a vied - Oscara. Jedna z hlavných postáv to konštatovala v rozhovore s miestnym kamenárom, ktorý práve vyrábal náhrobník pre žijúceho.

${ }^{11}$ Hovorový výraz pre dom.

${ }^{12}$ Viacerí starší kamenári uvádzali, že počas totalitného režimu bol nedostatok prírodného kameňa. Dovoz zo zahraničia nebol možný, ostávali len zdroje v rámci bývalého Československa (napr. liberecká žula, šluknovský sianit). Oproti umelému kameňu bol ale neporovnatel’ne nákladnejší a museli naň aj rok čakat. Príprava hrobu bola plánovaným, dlhšie trvajúcim procesom.
} 
budovania hrobov $\mathrm{z}$ trvácnejších materiálov sa v tomto období v mnohých mestách ${ }^{13}$, ale aj na vidieku začal objavovat nedostatok miesta na cintorínoch, čo ešte posilnilo tendencie zabezpečit si hrob dopredu.

Okrem priestorového vymedzenia hrobu na povrchu (rezervácia miesta, inštalovanie náhrobníka a obruby) niektorí pristupujú aj $\mathrm{k}$ budovaniu hrobky ${ }^{14}$ - vnútorných priestorov hrobu, spravidla pomocou betónových dielcov. Ide o taký stavebný zásah, ktorý vylučuje prítomnost hliny $\mathrm{v}$ hrobe. Začal sa intenzívnejšie objavovat práve za posledné zhruba dve dekády.

\section{Motivácie prípravy miesta posledného odpočinku}

U informátorov, najmä najstaršej generácie, prevažuje názor, že každý človek tak, ako má dom/byt na bývanie počas života, mal by mat aj hrob - miesto, kde spočinie po smrti a kde by si mali pozostalí a známi pripomínat jeho pamiatku. Jednotlivé názory sa výraznejšie rozchádzajú v otázke preferencií kostrového pochovávania alebo kremácie, taktiež aj skutočnosti, či sa príprava hrobu má odohrat' ešte počas života ${ }^{15}$. Hladala som odpovede na otázku - aké sú príčiny a motivácie prípravy hrobového miesta počas života. Uvádzam viacero $\mathrm{z}$ nich $\mathrm{v}$ poradí podl'a frekvencie ich výskytu.

Najčastejším dôvodom na vybudovanie hrobu je úmrtie jedného $z$ manželského páru, následne si preživší partner pripravuje miesto pri ňom (bud' sú pochovaní vedla seba, alebo „na sebe“). Takéto konanie, prítomné v našej spoločnosti už niekol'ko desat'ročí, pokladá väčšina informátorov za prirodzené a logické. Funguje predstava, že ak manželia obývajú jednu domácnosṫ (dom, byt), tak po smrti patria do spoločného hrobu. Aj v tomto konaní možno dekódovat obdobné prístupy pri zaobstaraní si hrobu ako pri kúpe miesta na bývanie - hrob pokladajú za d’alšiu podobu „bydliska“, v tomto prípade „bývania po smrti“.

Iným prípadom sú vopred pripravené prázdne hroby ešte žijúcich manželov, ale aj jednotlivcov. Začínajú takto konat zhruba vo veku $65-70$ rokov, vnímajú to ako súčast prípravy na smrt', respektíve „dobrej prípravy“. Vlastnia určité finančné prostriedky, ktoré nevyhnutne nepotrebujú na každodennú existenciu, a kúpu hrobu pokladajú za vhodný spôsob ich využitia. Mnohí príčiny takéhoto konania vysvetlujú tým, aby boli pripravení na smrt’ a boli „na poriadku“. Možno to interpretovat ako prejav myslenia a prípravy na vlastnú smrt', ale aj vysporiadania sa a zmierenia s vlastnou smrtelnostou. $Z$ výskumov jednoznačne vyplýva, že väčšiu iniciatívu v tejto sfére vykazujú ženy, v menšej miere išlo o vzájomnú dohodu, prípadne o iniciatívu muža. Muži sa v tomto smere vo

\footnotetext{
${ }^{13}$ Pozri napríklad článok v regionálnych novinách v Nitre o prípadoch hrobov l’udí, ktorí ešte žijú (Hojčušová M. 2006).

${ }^{14}$ Pod hrobkou rozumiem vymurovaný alebo z betónových dielcov vybudovaný vnútorný priestor hrobu, miesta na pochovanie.

${ }^{15}$ Viaceré názory respondentov $\mathrm{k}$ tejto otázke prezentuje materiál zozbieraný na začiatku 21. storočia (Jágerová 2008, s. 220 - 221).
} 
väčšine prípadov spoliehajú na ženy, kompetencie v tejto oblasti pripisujú ženám, podobne ako celkové záležitosti v starostlivosti o hrob či domácnost'.

$\mathrm{Na}$ druhej strane je nutné zdôraznit, že analyzované konanie má aj prestížny aspekt. Stavbou hrobu majitelia manifestujú svoj majetkový status na verejnosti (posudzovaný podla kvality a nákladnosti použitého materiálu), čo je taktiež nezanedbatel’ná motivácia. Budovanie hrobu si vyžaduje nemalé investície, často ide o dlhodobé úspory. Napriek tomu sú prázdne hroby, predovšetkým manželských dvojíc, čoraz frekventovanejším javom na cintorínoch. $V$ teréne som sa stretla aj s prípadmi, ked' hrob pripravený na pochovanie bol už takmer 20 rokov prázdny.

Iným dôvodom prípravy hrobu vopred je nezatažovat po úmrtí touto záležitostou vlastné deti, resp. pozostalých. Frekventovane sa vyskytovali vyjadrenia typu - „aby deti nemali potom starosti“. Ojedinele som sa stretla aj s dôvodom nedôvery rodičov voči det’om, že našetrené peniaze po ich smrti použijú na tento účel. Išlo však o raritné vyjadrenie, vyskytujúce sa v prípade narušených vztahov medzi rodičmi a det’mi.

Po zavádzaní evidencie hrobových miest a povinnosti platenia nájomného sa začali objavovat' aj d’alšie motivácie. Často bola dôvodom na vytvorenie vlastného miesta na pochovanie snaha zachovat hrob po rodinných príslušníkoch, ktorý už nemal kto udržiavat' (najmä starých a prastarých rodičov či iných príbuzných). Takýmto konaním chceli predíst' zrušeniu hrobu predkov a skutočnosti, aby toto miesto nebolo dané do užívania novým, „cudzím“ nájomníkom. Niektorí informátori deklarovali aj prípady rezervácie hrobov v blízkosti pochovaných príbuzných. Motivuje ich snaha, aby členovia rodiny boli pochovaní na jednom mieste, aby im nikto „cudzí“ nezabral miesto.

Aj ked’ to viacerí informátori priamo neuvádzali ako hlavný dôvod, resp. mnohí sa o tejto skutočnosti nezmieňovali, ich výpovede poukazujú na to, že prípravou hrobového miesta sa snažia zabezpečit si po sebe pamiatku. Ide o dôležitú motiváciu v sledovanej oblasti, ktorú dokladá aj tento výrok informátora: „Pomnik, to je pamiatka, taká kolektivna, ket’ príd’e človek na cintorín a vid’i tam fsetki tie mená pekñe popisané, to je taká úcta. " Odolný materiál akoby „zaručoval“ majitel'ovi, že zostane čo najdlhšie v kolektívnej pamäti danej lokality, zároveň postavenie náhrobníka zosnulému človeku je pokladané za prejav uctenia si jeho osoby. Na druhej strane sa neraz informátori zmieňovali aj o snahe niektorých pozostalých dodatočne kompenzovat drahým náhrobníkom narušené vzṫahy alebo nezáujem o zosnulého počas jeho života.

Ako už bolo uvedené, jednotlivé vopred pripravené hroby môžu mat aj stavebné zásahy pod úrovňou zeme vo forme hrobky, teda s vymurovaným alebo betónovými tvárnicami vystuženým vnútrom, bez prítomnosti hliny. $Z$ vyjadrení niektorých evidentne badat' snahu separovat telo od hliny, motiváciu nebyt' pochovaný, ,uložený“ v hline, ale tak, aby bolo v hrobe „sucho“ a „čisto“.

${ }^{16}$ Muž, nar. 1928, Nové Sady (okres Nitra). 
„Ňechcem bit do zemi zahrabani, ta kripta, to je dostojñejša. Zapačilo sa mi to, ket’ som bolf Kosicach na pohrebe, tam som to vid'el. Tu u nas to ma uš okolo 15 ludi", co ja viem. ${ }^{17} \mathrm{Jedna}$ žena mi povedala, že uš ňebud'em totu tarchu trimat', uš ňebud'em mat' na sebe tol'ko hlini, že añi

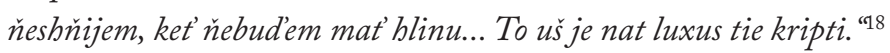

Takéto konanie informátori odôvodňovali aj praktickou funkciou - je dobré pripravit’ si hrobku dopredu, aby nemuseli hrobári kopat hrob, obzvlášt', ak k úmrtiu dôjde v zime, v nepriaznivom počasí. Pri pohrebe potom netreba odvážat preč hlinu, nie je nutné zabezpečovat hrobárov a predovšetkým - pohreb sa môže odohrat’ v „čistom“ prostredí, bez hliny. To sa z výskumných lokalít frekventovane prejavilo najmä v Soblahove (okres Trenčín), kde miestny kamenár vopred budoval hrobky a odpredával ich hotové prípadným záujemcom. Dokonca určité obdobie mal miestny obecný úrad zakúpených niekolko takto pripravených hrobov, aby ich mal v prípade potreby $\mathrm{k}$ dispozícii. Za posledné zhruba viac ako desat'ročie sa už aj na vidieku začalo objavovat' budovanie hrobov „na klúčc“, realizované kamenárskymi firmami, ktoré potom hotové hroby (podla želania aj s hrobkami) predávajú potenciálnym záujemcom.

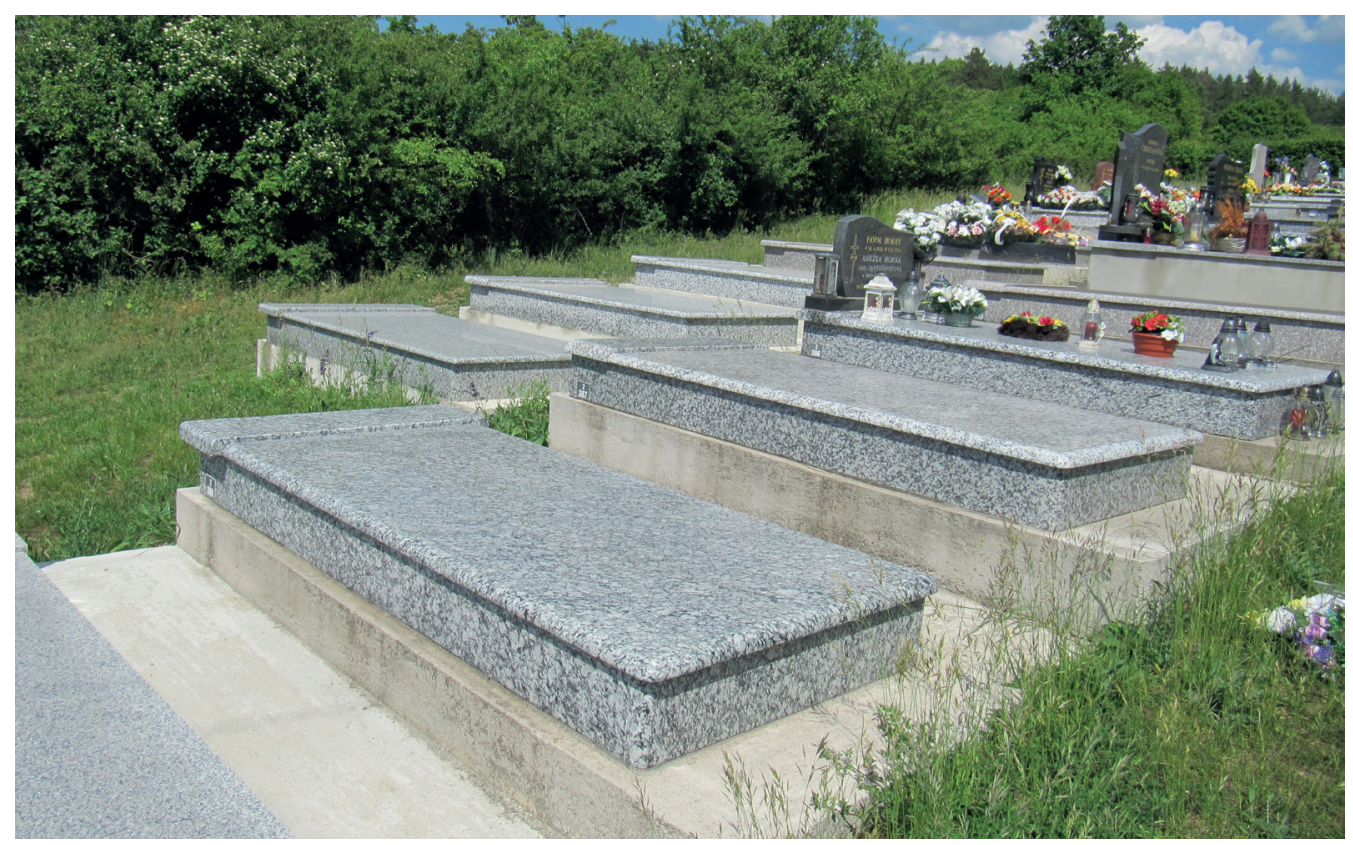

Skupina vopred pripravených hrobov, Soblahov (okres Trenčín), fot. M. Jágerová 2018

${ }^{17}$ Išlo o situáciu z roku 2001, zaznamenanú v obci Šumiac (okr. Brezno). Číselný údaj uvedený informátorom sa mi zdal nadsadený, žial', nepodarilo sa overit jeho platnost'.

${ }^{18}$ Muž, narodený v roku 1941, Šumiac. Z výskumného materiálu zo začiatku 21. storočia, spracovanom v publikácii Jágerová 2008, s. 175 - 176. 


\section{Spôsoby „obsadzovania“ a prípravy miesta v rámci cintorína}

Rozdielne prístupy $\mathrm{k}$ analyzovanej téme sa následne prejavujú $\mathrm{v}$ rôznych stratégiách prípravy hrobu vopred, taktiež $\mathrm{v}$ spôsoboch manifestovania tohto procesu navonok, resp. $\mathrm{v}$ niektorých prípadoch $\mathrm{v}$ snahe utajit ho. Budovanie vlastného hrobu môže prebiehat na základe viacerých motivácií, zmienených vyššie, ktoré sa premietajú do viacerých postupov v obsadzovaní miesta $\mathrm{v}$ cintoríne:

- Hrobové miesto pri manželskom partnerovi, s uvedením kompletných údajov (meno, priezvisko, rok narodenia), neraz aj s podobizňou, prípadne aj epitafom. Ide o najfrekventovanejší spôsob prípravy hrobového miesta ešte počas života, pričom ak zomrie jeden $\mathrm{z}$ manželov, ponechávanie miesta $\mathrm{v}$ spoločnom hrobe je v súčasnosti úplne bežnou a doslova ,automatickou“ záležitostou. $\mathrm{Na}$ takomto type náhrobníka môžu, ale aj nemusia byt umiestnené portréty manželského páru (jednotlivo alebo spoločná podobizeň).

- Hrobové miesto s kompletnými údajmi, zámerne bez podobizne jedného z partnerov. Ide o spôsob, ked’ ešte žijúci manželský partner má síce na náhrobníku svoje meno, dátum narodenia, ale nechce tam mat' svoju podobizeň, pre ktorú je evidentne ponechané miesto (najčastejšie v podobe vypieskovaného oválu, obdľ̌̌nika na náhrobníku). Je to možné v prípade, ak ide o individuálne podobizne/fotografie, dodatočne umiestňované až po úmrtí dotyčnej osoby. Viacerí príslušníci najstaršej generácie nepovažujú za problematické dat si ešte počas života svoje meno na náhrobník, ale neraz som sa stretla s odmietaním umiestňovania fotografí, dokonca takéto konanie vyvoláva občas aj u príslušníkov najstaršej generácie pohoršenie.

- Prázdny hrob manželskej dvojice/prázdny individuálny hrob - ide o prípady, ked' $\mathrm{v}$ hrobe nie je zatial' nik pochovaný, je evidentne prázdny. Tento variant sa vyskytuje v dvoch podobách: jednak prázdny hrob manželskej dvojice s kompletnými údajmi, s podobizňou, epitafom, alebo prázdny hrob s údajmi, ale bez podobizne či epitafu. Takýto hrob sa dá spol'ahlivo identifikovat v čase novembrových spomienkových sviatkov, ked' je rozoznatelný kvôli absentujúcej výzdobe. Miestni obyvatelia hroby ešte žijúcich poznajú a z pochopitel'ných dôvodov tam neumiestňujú dekorácie, nevykonávajú spomienkové úkony. To isté platí aj $\mathrm{v}$ prípade hrobu manželov, z ktorých je jeden ešte nažive - na prázdnej polovici hrobu sa dekorácie a sviečky neumiestňujú.

- Miesto pre manžela/manželku na náhrobníku bez uvedenia mena, údajov, prípadne podobizne. Ide o raritné prípady, nákladnejší variant prípravy, nakol'ko dodatočne vyhotovit’ totožný nápis je problematické. Vyžaduje si to demontáž náhrobného kameňa, ktorá predstavuje určité riziko. Náhrobník sa môže kedykolvek poškodit, či už pri prevoze, demontáži alebo opätovnej montáži. Kamenárske firmy ho neodporúčajú, a preto je ojedinelý. Optimálnym variantom 


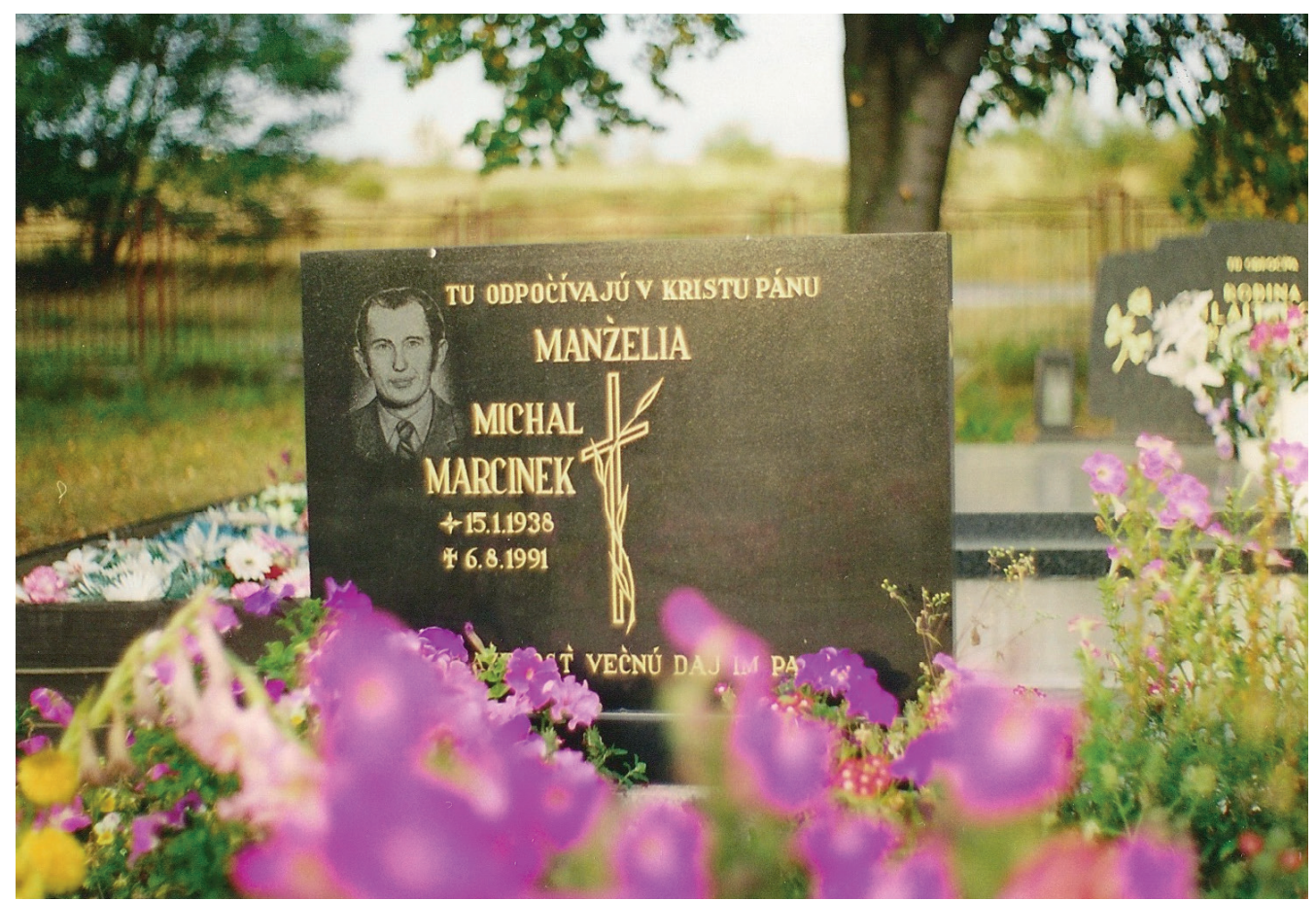

Náhrobník s vol'ným miestom pre údaje o ešte žijúcej manželke, Dačov Lom (okres Vel'ký Krtíš),

fot. M. Jágerová 2001

je umiestnit všetky údaje hned' pri prvotnej výrobe. Rok úmrtia sa dorába dodatočne priamo na cintoríne, ale je často viditel'ne rozdielny (lesk písma, niekedy tvar a pod.), je náročnejšie ho vyhotovit tak, aby nepôsobil rušivo. Naopak, pre výskumníka je to jasný dôkaz toho, že náhrobník bol vyrobený ešte počas života dotyčných. Navyše kamenári si za dodatočné dorábanie údajov účtujú ovel’a vyššie poplatky (spravidla osobitná taxa za každé písmeno/číslicu) ako v prípade ich vyhotovenia pri prvotnej výrobe náhrobníka ${ }^{19}$.

- Náhrobníky s vynechaným miestom pre údaje d’alších členov rodiny - tento variant sa vyskytuje $\mathrm{v}$ prípade úmrtia malých detí, mladých slobodných ludí, resp. manželských partnerov, ktorí zomreli v mladšom, produktívnom veku. Na náhrobníku je evidentná snaha do budúcna rozširovat údaje o d’alších zosnulých, nakolko meno prvého zosnulého je umiestnené excentricky, s vynechaným

${ }^{19}$ Počas výskumu jeden z kamenárov pôsobiaci v okrese Lučenec hovoril o prípade, ked’ si zákazníčka na náhrobník uviedla dátum úmrtia v podobe dvoch začiatočných číslic (19..), pričom zomrela až po roku 2000. Bolo potrebné komplikovane odstránit’ starý údaj, dorobit’ aktuálny, čo si vyžadovalo demontáž náhrobníka, jeho odvoz do dielne, následne opätovné osadenie. Náklady spojené s opravou roka boli neúmerne vysoké, pričom išlo len o 4 číslice. 
vol'ným miestom pre d'alších. Vynechané vol'né miesto sa objavuje v prípadoch, ak ide o partnerov, ktorí sú nielen mladšieho veku (cca 40 - 50-roční), ale aj $\mathrm{v}$ prípadoch, ak partner (člen rodiny) nie je stotožnený s myšlienkou umiestnenia svojho mena na cintoríne.

- Vol'né hrobové miesta so zakrytým náhrobníkom (zahalený fóliou), staršie formy - obloženie doskami alebo príprava hrobu (obruby, prípadne zakrytie platňou) bez náhrobníka, ktorý si majitelia odkladali mimo cintorína (v pivnici, humne...), aby nebol inštalovaný na verejnosti. $\mathrm{S}$ takýmito prípadmi som sa v teréne stretávala na začiatku 21. storočia (napríklad v lokalite Sucháň v Honte). Niekol'ko takýchto hrobov bez osadených náhrobníkov sa vyskytuje takmer v každom vidieckom cintoríne. Neraz je náhrobník už vyrobený, zakúpený, ale nie je osadený. Majitelia si neželajú mat na cintoríne svoje mená ešte počas života.

- Vol'né miesta pre rodičov zosnulých detí - ak zomrie diet’a (nie však novorodenec alebo diet’a $v$ dojčenskom veku), resp. mladý slobodný človek, ešte žijúci rodičia si neraz budujú miesto na pochovanie spolu s ním, čo sa odráža aj na umiestňovaní ich mien na náhrobník. Ak ide o prípad úmrtia mladších detí dnes mávajú zriedkavo svoj vlastný hrob, často sú pochovávané do hrobu rodinných príslušníkov, resp. „na rodinných príslušníkov“ (prababku, pradedka...), s čím súvisí aj zánik kedysi samostatných detských častí v cintorínoch. Neraz však takýto novovytvorený hrob poskytne bázu na prípravu rodinného hrobu niektorí rodičia si na pomník okrem mena dietata umiestnia svoje mená, hoci ide o ludí v strednom veku (45-roční rodičia).

- Mená ešte žijúcich detí umiestnené na náhrobníku mútvych rodičov/rodiča v jednej zo skúmaných lokalít - vo Vlachove (okres Rožňava) - som sa dokonca stretla s umiestnením mena syna na náhrobníku zosnulej matky, pričom syn bol narodený v roku 1979. Informátori to odôvodňovali faktom, že ide o zdravotne postihnutého slobodného syna. Ked' umrela jeho matka (rok 2017), jej manžel dal vyrobit náhrobník, na ktorom figurujú mená všetkých členov rodiny. Podobný prípad som zaznamenala v roku 2000 v Nových Sadoch, ale išlo o rozvedeného syna, ktorý sa vrátil po rozvode spät do rodičovského domu. Pri úmrtí jedného $\mathrm{z}$ rodičov bolo jeho meno umiestnené na náhrobník spolu s rodičmi, hoci v tom čase išlo o pätdesiatnika. Ide jednoznačne o snahu, aby rodina ostala pohromade aj v prípade úmrtia, snahu „zaopatrit“ svoje diet’a v otázke „bývania po smrti“. Takéto prípady opätovne potvrdzujú motiváciu budovania spoločného rodinného hrobu.

- Rezervácia hrobového miesta - ojedinele sa objavuje aj taký spôsob zabezpečovania miesta na pochovanie, ktoré je označené len tabul'kou s nápisom „rezervácia“, „rezervované“, bez akýchkolvek stavebných zásahov. V takýchto prípadoch sa predpokladá, že $\mathrm{v}$ blízkej budúcnosti dôjde $\mathrm{k}$ stavebnej úprave (obruba, náhrobník, prípadne hrobka...). V niektorých obciach označujú takýto hrob 
spomínanými nápismi, pričom viaceré obsadené miesta nemusia byt takto označené, len evidované v evidencii hrobových miest na miestnej samospráve.

\section{Záver}

Z hladiska zmien $\mathrm{v}$ prístupe $\mathrm{k}$ priestoru cintorína je dôležitý poznatok, že súčasné pohrebiská neinformujú návštevníka len o pochovaných, ale aj o žijúcich a ich materiálnej príprave na smrt'. Za posledné desatročia živí čoraz viac zasahujú do priestoru určeného kedysi výhradne mŕtvym, pričom formujú nadzemnú, ale frekventovane aj podzemnú čast' (budovanie hrobiek). Snažia sa „osvojit“ si dané miesto, pripravit si ho podla vlastných predstáv o „bývaní" po smrti (materiál, tvar, realizácia vlastných estetických kritérií..). Takéto konanie pokladajú za súčast prípravy na finálnu fázu svojej existencie. Sami sebe darujú náhrobník, taktiež epitaf, ktorý je v takom prípade len formálny.

Realizácia názoru najstaršej generácie o tom, že každý má mat svoj hrob, miesto, kam je možné príst' a uctit si jeho pamiatku, sa časovo posunula ešte pred samotné úmrtie dotyčného. Na druhej strane je nutné opät zdôraznit, že nie všetci príslušníci najstaršej generácie takéto konanie schvalujú. Pre niektorých sa zdá predčasné pozerat’ sa pri každej ceste na cintorín na svoje meno či dokonca fotografiu na náhrobníku.

Cintorín možno v súčasnosti vnímat aj ako miesto plné „domov“, ktoré si niektorí budujú dopredu. Toto konanie prezentuje snahu zabezpečit si pamiatku na seba samého v kolektívnej pamäti lokálneho spoločenstva. Najčastejšie sa príprava hrobu realizuje v prípade úmrtia manželského partnera, menej v prípade úplne prázdnych hrobov. Ide o konanie, ktoré je zastúpené tak u majoritného, ako aj rómskeho obyvatel'stva. $\mathrm{Aj}$ tam fungujú rovnaké stratégie v tejto oblasti, čoho dôkazom je zo skúmaných lokalít Liptovská Teplička a Polomka, pričom treba poznamenat, že ide o majetnejších jedincov.

Presný počet prázdnych, vopred pripravených hrobových miest v jednotlivých lokalitách je pomerne tažké zistit - nie všetky takéto hroby sú označené, resp. v mnohých prípadoch mítvi ešte nemajú aktualizované dátumy úmrtia. Pri označených hroboch možno v niektorých lokalitách zaznamenat aj niekol'ko desiatok vopred pripravených hrobových miest, neraz sa stretávame aj s rezerváciou bez náhrobníka. Rodinný hrob je dnes niečo, čo každý chce mat', a tento trend je spojený s pocitom privátneho vlastníc$\operatorname{tva}^{20}$. Velmi frekventované sú motivácie, aby bola rodina „pokope“, pochovaná na jednom mieste. Práve tieto vysvetlenia majú primárny vplyv na stratégie výberu miesta a budovania si hrobu.

V závere prezentujem aj niekol'ko postrehov, ktoré súvisia so zmenami v pohrebnom obyčajovom cykle ako dôsledok analyzovaného konania. $V$ prvom rade je nutné poznamenat', že v prípade vopred pripraveného hrobu s náhrobníkom stratili opodstatnenie drevené kríže s menom zosnulého, ktoré fungovali nielen ako označenie hrobu bezprostredne po jeho navíšení, ale boli taktiež nesené na čele pohrebného sprievodu,

\footnotetext{
${ }^{20}$ Habinc 1999, s. 152.
} 
čím zvyšovali jeho informatívnu stránku. Ich zabezpečovanie a osadenie na hrob je podla informátorov dnes už zbytočné, nakol'ko hlavnou funkciou kríža bolo označit', pomenovat čerstvé miesto pochovania, čo pri vopred pripravených hroboch s menami ich majitel'ov už nie je potrebné.

Ak má zosnulý pripravenú murovanú hrobku, nie je nutné zabezpečovat hrobárov na výkop, čo je praktické najmä počas zimy či v čase nepriaznivých poveternostných podmienok. Počas takéhoto pohrebu je okolie hrobu bez hliny a blata. Zjednodušila sa manipulácia pri jeho uzavretí, spočívajúca len v položení platní na povrch. Namiesto hrobárov čaká po skončení pohrebných obradov obd’aleč kamenár (murár), ktorý dá na hrob tenkú vrstvu malty alebo silikónu a navrch položí kamennú platňu. V takýchto prípadoch taktiež stratila opodstatnenie obyčaj hádzania hrudy hliny na truhlu zosnulého, ktorá plnila funkciu poslednej rozlúčky a vzdania pocty zosnulému. Hlina je v takýchto prípadoch úplne vylúčená $z$ akýchkolvek úkonov.

Prispevok bol vypracovaný v rámci riěsenia grantu APVV-16-0115 Sociokultúrny kapitál uispešných obci ako zdroj udržatelného rozvoja slovenského vidieka (Socio-cultural capital of successful villages as a source of sustainable development of the Slovak countryside).

\section{Bibliografia:}

Aláč J. 2015, Tu spocíva kvet, co zanechal svet. Novohradské ludové nábrobniky a ich prezentácia $v$ Hornom Tisovniku. Obec Horný Tisovník.

Bednárik R. 1949, Ludové nábrobniky na Slovensku. Matica slovenská, Martin.

Burlasová S. 2009, Slovenské pohrebné nariekania. Lament v hudbe, Ústav hudobnej vedy SAV, Bratislava, s. 7-32.

Habinc M.1999, Visiting and tending the graves with a special referencies to the case study in Br̈eznice, "Etnolog", 9/1999, č.1., s. 145- 62.

Jágerová M. 2008, Posledné zbohom... Súčasné pohrebné obyčaje. Univerzita Konštantína Filozofa, Nitra.

Kligman G. 1988, The Wedding of the Death. Ritual, Poetics and Popular Culture in Transylvania. London.

Plotnikova A. 1999, The Earthly Loci of Death: the Coffin, the Grave, the Cemetry, "Etnolog", 9/1999, č. 1., s. 205-215.

Sedakova O. 1990, Tema "doli“v pogrebal'nom obrjade (vostočnoslovjanskij i južnoslorjanskij material), [w:] Issledovanija v oblasti balto-slavjanskoj duchovnoj kultury - Pogrebalnyj obrjad. Moskva, s. 54-64.

Sikora S. 1986, Cmentarz. Antropologia pamięci, "Polska Sztuka Ludowa“ č. 1-2, s. 57-67.

Vakarelski Ch. 1990, Blgarski pogrebalni običai, Sofia. 
Hanzl Z. - Jiráček A. 1993, Nábrobek - komunikativni a integrujíci činitel na českém venkové, “Český lid“, Vol 80, No. 2, s. 123-137.

\section{Źródła internetowe}

Hojčušová M. 2006, Hoci nezomreli, majú už svoj hrob. Dostupné na: https://mynitra.sme. sk/c/4738824/hoci-nezomreli-maju-uz-svoj-hrob.html, 30.11.2018.

https://www.facebook.com/CintorinyCemeteries/photos/a.1056437627768068/135353760139 1401/?type=3\&theater, 15. 2. 2018. 
